\title{
血栓を測る：脳梗塞の血栓止血学的評価
}

山崎昌子*

\section{Assessment of thrombogenicity in stroke}

Masako YAMAZAKI

要約 : 脳梗塞で血栓止血学的評価が重要な役割を果たすのは, 血栓性素因を 基礎に発症する特殊な脳梗塞の診断やワルファリンのモニタリングである. 一方, 脳梗塞の病態把握, 再発リスク予測や抗血栓療法の有効性・安全性評 価についても, 血栓止血学的評価の有用性が示唆されている. 多くの検討が 行われている非并膜症性心房細動では, 脳梗塞や出血の臨床的なリスクスコ アにD-ダイマーを組み合わせると心原性脳塞栓症や抗凝固療法中の出血の予 測精度が改善することが示唆されており, 血栓止血学的評価は脳梗塞の診断 と治療の個別化に有用な可能性がある。ただし, 脳梗塞の基礎病態は複雑か つ多様なため, 血栓形成過程の一側面を反映するに過ぎない単一の検査だけ で評価することは難しい. 複数の血栓止血学的指標から慎重に評価し, 画像 診断など他のバイオマーカーと組み合わせて総合的に解釈する必要がある。
山崎昌子

1987年

日本医科大学医学部卒業

1987年 1991年 東京女子医科大学大学院 (神経内科学専攻)

1991年〜現在

東京女子医科大学 神経内科

Key words: hemostatic marker, platelet function test, coagulation test, subtypes of stroke, risk prediction

\section{1.はじめに}

脳梗塞は動脈硬化が基盤となって血栓が形成さ れ，脳動脈が閉塞されることによって発症する血栓 性疾患である。脳梗塞の診断と治療の基本となるの は, 症状・神経学的所見やリスク因子に関する臨床 情報と画像検査所見である。一方，血栓止血に関連 した検査が重要な役割を果たすのは，血栓性素因を 基礎に発症する特殊な脳梗塞の診断やワルファリン のモニタリングである。脳梗塞の病態, 再発リスク や抗血栓療法の評価についても血栓止血関連の検査 の有用性が示唆されているが, 日常臨床に推奨され る段階ではない.

\footnotetext{
*責任者連絡先：

東京女子医科大学医学部神経内科学

干 162-8666 東京都新宿区河田町 8-1

Tel: 03-3353-8111, Fax: 03-5269-7617

E-mail:myamazak@nij.twmu.ac.jp
}

\section{2. 特殊な脳梗塞の診断}

高血圧症・糖尿病・脂質異常症・喫煙などの動脈 硬化の危険因子をもたず動脈硬化所見が明らかでは ない患者，血栓症の既往歴または家族歴がある患者 や若年者に発症した脳梗塞では，動脈硬化以外の特 殊な基礎病態が疑われる。このような脳梗塞の原因 または危険因子として，さまざまな先天性および後 天性の血液凝固異常症が報告されている $(\text { 表 } \mathbf{1})^{1}$. この中で脳梗塞の原因として頻度が高いものは抗 リン脂質抗体症候群であり, ペリン起因性血小板 減少症，ホモシステイン血症，リポ蛋白(a) [ Lp (a) ] 血症なども脳梗塞の危険因子として注目されてい る1．先天性血栓性素因による血栓症のほとんどは 深部静脈血栓症・肺塞栓症で, 脳梗塞の頻度は高く ない1).

特殊な病態が疑われる脳梗塞のスクリーニングに は, 活性化部分トロンボプラスチン時間(APTT), プ ロトロンビン時間 $(\mathrm{PT})$, フィブリノゲン，アンチト 
表 1 脳梗塞の原因となりうる血液凝固異常症

先天性血栓性素因
凝固制御因子の機能不全
アンチトロンビン欠損症
プロテインC 欠損症
プロテイン S 欠損症
活性化プロテイン C 抵抗性
アンチトロンビン抵抗性(異常プロトロンビン)
線溶系因子の機能不全
プラスミノゲン異常症
組織プラスミノゲンアチベーター放出障害
プラスミノゲンアクチベーター・インヒビター
タイプ1 過剩症
凝固因子の増加
プロトロンビン $\mathrm{G} 20210 \mathrm{~A}$
第 VII 因子増加症
その他
異常フィブリノゲン血症
高リポ蛋白(a)血症
高ホモシステイン血症
後天性血栓性素因
抗リン脂質抗体症候群
ヘパリン起因性血小板減少症
高ホモシステイン血症
悪性腫瘍に伴う播種性血管内凝固症候群

(文献 1 より引用改変)

ロンビン $(\mathrm{AT})$ 活性, プロテイン $\mathrm{C}$ 活性, プロテイン $\mathrm{S}$ 活性, ループスアンチコアグラント, 抗カルジオ リピン抗体，抗 $\beta_{2}$-glycoprotein I 抗体，ホモシステ インや $\operatorname{Lp}(\mathrm{a})$ が検査されている.

\section{3. 血栓止血関連の検査}

血栓止血に関連した検査(表 2)の中で，本来の検 査目的が出血傾向の診断である凝固時間や血小板凝 集能などは, 脳梗塞のような血栓傾向の評価の精度 は低く, 抗血栓薬の評価に利用されている。一方, トロンビン産生，フィブリン生成と分解および血小 板活性化により血液中に遊離される半減期の短い反 応生成物は, 凝固系, 線溶系や血小板活性化の分子 マーカーとして高感度に測定され，生体内で時々 刻々と変化する活性化状態を反映して鋭敏に变動す るため血栓傾向の評価に有用である ${ }^{1)}$.

血栓止血に関連したそれぞれの検査は血栓形成に かかわる反応の一側面や一段階を反映しているに過
ぎず，単一の検査で血栓形成の全体像を把握するこ とはできない，また，検査結果には測定条件が大き く影響するものの，標準化が不十分という問題もあ る.脳梗塞患者の複雑な病態を評価するためには, 複数の検査結果を組み合わせて総合的に解釈する必 要があると考えられるが, 日常臨床で測定可能なも のは限られている。

\section{1）凝固系に関連する検査}

凝固系の検査は大きく, 血液の凝固能 - 凝固予備 能をみる検査と分子マーカーに分けられる。脳梗塞 患者の生体内における凝固立進とそれに続く線溶活 性化の評価には, トロンビン・AT 複合体(TAT), プ ロトロンビンフラグメント $1+2(\mathrm{~F} 1+2)$, 可溶性フィ ブリン $(\mathrm{SF})$ やフィブリンモノマー複合体 $(\mathrm{FMC})$ など の凝固活性化マーカーと D-ダイマーが用いられて いる。 これらのマーカーは, 脳梗塞患者の血栓形成 の病態や再発リスクと治療効果を評価するのに有用 であることが示唆されている1).

一方, APTT P PT は, 脳梗塞の原因となる血液 凝固異常症のスクリーニングや抗凝固薬の薬効評価 に利用されている. 抗凝固薬の薬効評価について は, PT の国際標準比(INR)によるワルファリンのモ ニタリングは確立しているものの, それ以外は適切 な評価方法が確立していない. トロンビンや活性化 第 X 因子 $(\mathrm{Xa})$ といった単一の標的分子を阻害する直 接経口抗凝固薬 $(\mathrm{DOACs})$ のような薬剤は, 複数の凝 固因子が影響する APTTやPTよりも，標的分子の 抑制から薬効を評価することが望ましい。しかし臨 床的には DOACs の血中濃度と APTT や PT が正相 関することから APTT や PT がチェックされ, 高度 の延長が認められる場合に DOACs の血中濃度が過 剩に高く, 凝固系が過度に抑制されていると判断さ れている2).

\section{2）血小板系の検査}

血小板機能検査も大きく, 血小板活性化刺激に対 する反応性を評価する検査と血小板活性化マーカー に分けられる。

血小板活性化マーカーは, 活性化に伴い膜表面に 発現する分子(P-セレクチン：PS, CD40 リガンド： CD40L 他), 内部顆粒から放出される物質 ( $\beta$-トロン ボグロブリン： $\beta$-TG，血小板第 4 因子：PF4 他)や 活性化により生じる代謝産物(トロンボキサン $\mathrm{B}_{2}$ 他) 
表 2 血栓止血関連の検査

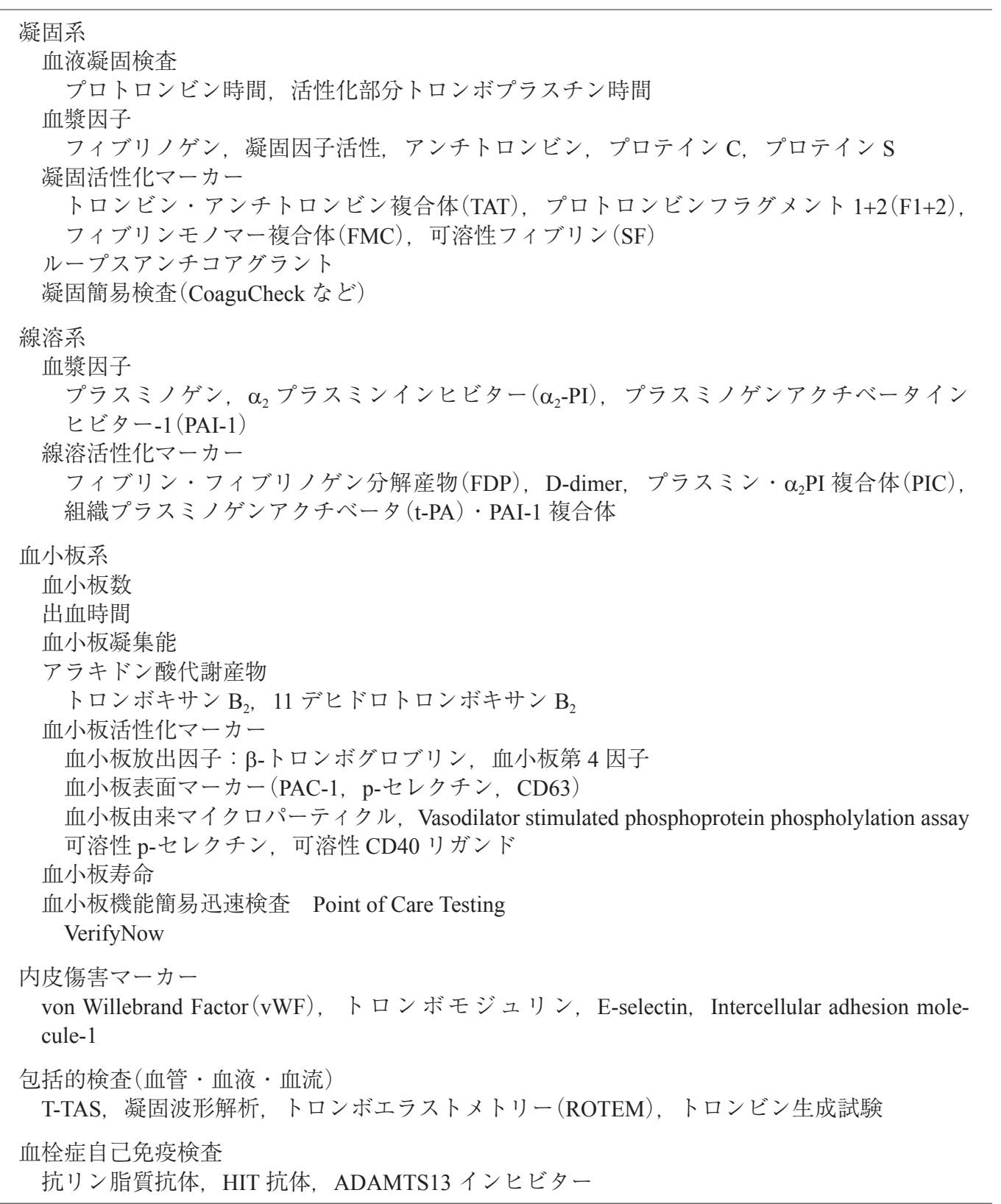

(文献 1 より引用改変)

を，フローサイトメトリーや ELISA など高感度の 方法を用いて測定するものである。凝固線溶活性化 マーカーと同様に日常臨床で検査しやすいのは $\beta-\mathrm{TG}$ と PF4であるが，これらは採血や測定過程で $\alpha$ 顆粒 から放出されやすく, 生体内の血小板活性化状態の 指標としての信頼性は低い。研究的に血小板活性化 の鋭敏な指標として用いられているのは，血小板表 面や血漿中の PS と CD40L, 血小板単球複合体や血
小板由来マイクロパーティクルなどで, 再発リスク や治療効果との関連が検討されている ${ }^{1)}$.

活性化刺激に対する血小板の反応性は，脳梗塞患 者では抗血小板薬の薬効評価を目的に測定されるこ とがほとんどである。患者から採取した血小板に in vitro で活性化刺激を加え，活性化に必要な刺激の 強度や，刺激により惹起された凝集や活性化の程度 から抗血小板効果が評価されている3)。 しかし，抗 
血小板薬の薬理作用を特異的に評価できる検査はな いこと, 検査值の個人差が大きいため判定が難しい こと，専門施設以外では測定が困難なことなどの問 題から, 新しい検査法の確立が望まれている.

(1) Point of Care Testing (POCT)

血小板機能検査のゴールドスタンダードである透 過光法による血小板凝集能は, 標準化など方法上の 問題から, 多施設のデー夕を集積して心血管イベン トとの関連を検討すること自体が困難である。この 問題は, ベッドサイドで簡便かつ迅速に測定できる POCT の装置ではかなりの部分が解決される.

POCT の中で VerifyNow ${ }^{\circledR}$ は, アスピリンカート リッジではアラキドン酸, $\mathrm{P} 2 \mathrm{Y}_{12}$ カートリッジでは アデノシン二リン酸(ADP)によって血小板を活性化 し, 活性化された血小板がカートリッジ内のフィブ リノゲンでコーティングされたビーズに結合する際 に変化する光透過度から Aspirin Reaction Units(ARU) や P2 $Y_{12}$ Reaction Units(PRU)を評価する装置である. $3.2 \%$ クン酸ナトリウムを用いて採取した全血を, 採血管ごとそのままカートリッジに挿入するという 極めて簡単な手技で，5分程度で測定が完了するこ とが大きな利点である.ADP 受容体阻害薬の開発 試験などにおいて PRUが血小板反応性の指標に用 いられ，冠動脈疾患ではクロピドグレル投与下の PRU が高い集団の心血管イベント再発リスクが高 いことが示唆されている ${ }^{4,5)}$. ただし, PRUを指標 にクロピドグレルの増量やプラスグレルへの変更を 行った試験において，心血管イベントの抑制は示さ れなかった6,7).

(2)包括的検査

凝固や血小板だけではなく, 血流や線溶なども含 めた血栓形成を測定する装置が開発されている。こ の中の Total Thrombus formation Analyzing System(T$\left.\mathrm{TAS}^{\circledR}\right)$ は血流下に扮ける止血・血栓形成の解析を目 的とした, マイクロチップを用いた自動式 flow chamber system である ${ }^{8)}$. T-TAS ${ }^{\circledR}$ では, マイクロチップ の流路内部にコラーゲンがコーティングされた PL チップおよびコラーゲンと組織因子がコーテイング

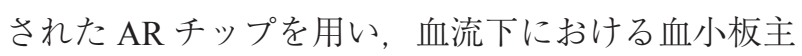
体の血栓および血小板・フィブリン混合血栓の形成 過程を定量的に評価できる。包括的な検査で従来の 検査よりは生理的条件に近い反面, 血栓形成能に影
響する要因が多く，測定結果が幅広く分布するた め, 結果の解釈が難しい. 抗血小板療法の評価につ いては, PL チップでの血栓形成能 (PTF) はアスピ リンでもクロピドグレルでも抑制され ${ }^{8-10)}$ ，アスピ リン・クロピドグレル併用療法とそれぞれの単独療 法の差も検出できるという特徵を持つ ${ }^{9,10)}$. 基礎病 態の評価については, 脳梗塞発症リスクが高い頸動 脈病変との関連が示唆されている ${ }^{10)}$. クロピドグレ ル療法中の慢性期脳梗塞では, PTF や PS が頸動脈 の狭窄度と弱い正の相関を示したのに対し ADP 凝 集やPRU は狭窄度と関連がないこと, ADP 凝集は 高度狭窄でも軽度狭窄と同等に抑制されているのに 対しADP 以外の経路も含めた全体的な血小板反応 性は高度狭窄で高いことが示唆された ${ }^{10)}$.

\section{4. 脳梗塞臨床病型による相違}

脳梗塞の基礎病態や血栓形成メカニズムには臨床 病型による相違がある。アテローム血栓性脳梗塞は, 大動脈弓・頸部・脳内の主幹動脈のアテローム硬化 性病変を基盤とし, 血小板が主要な役割を果たして 血栓が形成され発症する。酸化ストレス・高血糖・ 高コレステロールなどの刺激による全身の内皮細胞 傷害, 炎症細胞から放出される生理活性物質やマク ロファージに大量に発現する組織因子などアテロー 厶硬化の進展過程におけるさまざまな反応は, 血小 板や凝固系を活性化する要因となる。アテローム硬 化巣(プラーク)上の血栓の増大に伴う血流低下は, さらに凝固系を活性化する. ラクナ梗塞は, アテロー 么硬化とは異なる小血管病と総称される病態を基盤 に小さな血栓が形成され，細い穿通枝が閉塞されて 発症する小梗塞である。一方, 心原性脳塞栓症は心 内に形成された血栓や, 心内を経由した比較的大き な栓子が脳血管を閉塞することにより発症する。心 腔内や静脈系では, 血流うっ滞などから凝固立進状 態となり血栓が形成されるが, 産生されたトロン ビンは血小板も活性化する.

このような脳梗塞の基礎病態は凝固・線溶・血小 板活性化マーカーに反映され, 臨床病型により異 なった上昇パターンを示すことが報告されてい $3^{1,11-14)}$. アテローム血栓性脳梗塞では血小板活性 化マーカーの上昇が主体で凝固活性化マーカーも軽 
表 3 脳梗塞の臨床概念による病型分類と凝血学的検査

\begin{tabular}{|c|c|c|c|}
\hline 臨床概念 & 心塞栓性 & アテローム血栓性 & ラクナ \\
\hline 病因 & 左房 - 左室 · 静脈血栓 & 大血管の樕状硬化 & 穿通枝の細動脈硬化 \\
\hline \multirow[t]{2}{*}{ 危険因子 } & 心内塞栓源 & 高血圧, 糖尿病 & 高血圧 \\
\hline & & 高脂血症, 契煙 & \\
\hline 梗塞部位·大きさ & 皮質/大 & 皮質/中～大 & 皮質下/小 \\
\hline 血栓の組成 & フィブリン主体 & 血小板主体 & 不明 \\
\hline 凝固系分子マーカー & $\uparrow \uparrow$ & $\uparrow$ & $\rightarrow \sim \uparrow$ \\
\hline 線溶系分子マーカー & $\uparrow \uparrow$ & $\rightarrow \sim \uparrow$ & $\rightarrow$ \\
\hline 血小板活性化マーカー & $\uparrow$ & $\uparrow \uparrow$ & $\rightarrow \sim \uparrow$ \\
\hline 抗血栓療法 & 抗凝固療法 & 抗血小板療法 & 抗血小板療法 \\
\hline
\end{tabular}

(文献 1 より引用)

度〜中等度に上昇し，心原性脳塞栓症では凝固活性 化マーカーの高度な上昇と血小板活性化マーカーの 上昇が認められ，ラクナ梗塞ではいずれの分子マー カーも上昇しないという報告が多い1,11)(表 3)。た たし，凝固・線溶・血小板活性化マーカーの上昇に は脳梗塞の基礎病態だけではなく，発症後の二次的 な凝固・線溶・血小板の活性化，糖尿病や癌などの 併存疾患や採血・検体処理の影響も反映される。単 一の分子マーカーのみが上昇を示す場合にはとく に，結果を慎重に解釈する必要がある。

\section{5. 心原性脳塞栓症の病態評価}

心原性脳塞栓症については, 脳梗塞発症リスクや 抗凝固療法の有効性・安全性と D-ダイマーを中心 とした分子マーカーとの関連が数多く報告されてい る $^{1,11,12,15-17)}$.

\section{1）脳梗塞発症・再発リスクとの関連}

心原性脳塞栓症の基礎心疾患の大多数は非弁膜症 性心房細動(NVAF)である。NVAFでは, TAT, F1+2, D-ダイマー, プラスミン $\alpha_{2}$ プラスミンインヒビター 複合体, von Willebrand Factor(vWF), PS や CD40L などが上昇することが報告されている ${ }^{1,18)}$ ，とくに D-ダイマーは，心内血栓の増大や退縮，もやもや工 コーなどと関連して変動し ${ }^{15,17)}$, 心原性脳塞栓症を 含む心血管イベント発症リスクの評価に有用なこと が示唆されている ${ }^{19,20)}$ 。さらに，脳梗塞巣の大きさ や機能予後との関連も報告されている ${ }^{21)}$ 。一方 PS
は心房細動そのものではなく，心血管疾患の基礎病 態を反映して上昇することが示唆されている22).

NVAF の心原性脳塞栓症発症リスクは基礎病態に より異なるため，個別にリスクを予測して抗凝固療 法の適応を判断する必要がある。臨床的には高血圧 症 - 心不全 - 高齢 - 糖尿病 - 脳梗塞の既往からスコ ア付けする $\mathrm{CHADS}_{2}$ スコア ${ }^{23)}$ を用いてリスクを評 価し，高リスク患者に抗凝固療法が行われている. 一方, NVAF 患者の心原性脳塞栓症発症リスクの予 測にはバイオマーカーも有用で，トロポニン，脳性 ナトリウム利尿ペプチドとともにD-ダイマーや vWF の有用性が示唆されている ${ }^{24-30)}$. PS や CD40L はNVAFで上昇するものの発症リスクとの関連は そしいことが報告されている31).

$\mathrm{CHADS}_{2}$ スコアは心原性脳塞栓症の機能予後とは 関連しない. $\mathrm{CHADS}_{2}$ スコア 0 または 1 点とリスク が低くてもいったん発症した脳梗塞が重症なことは 少なくないことから，より詳細な $\mathrm{CHA}_{2} \mathrm{DS}_{2}$-VASc スコアを用いて低リスクの患者の中でも比較的脳梗 塞発症リスクの高い患者を評価し，積極的に DOACs で予防することが推奨されている ${ }^{23)}$. さら に, $\mathrm{CHA}_{2} \mathrm{DS}_{2}$-VASc スコアが低くてもD-ダイマー や vWF が高いと脳梗塞をはじめとするイベント発 症リスクが高くなり，両者を組み合わせると予測精 度が上がることも示唆されている $\left(\right.$ 図 1 ${ }^{27-30)}$ 。個別 の患者で脳梗塞発症リスクの予測精度が上がれば, 脳梗塞の効率的な予防が期待できる。ささらに、リス クが極めて低い患者を選別できれば，過剩な抗凝固 


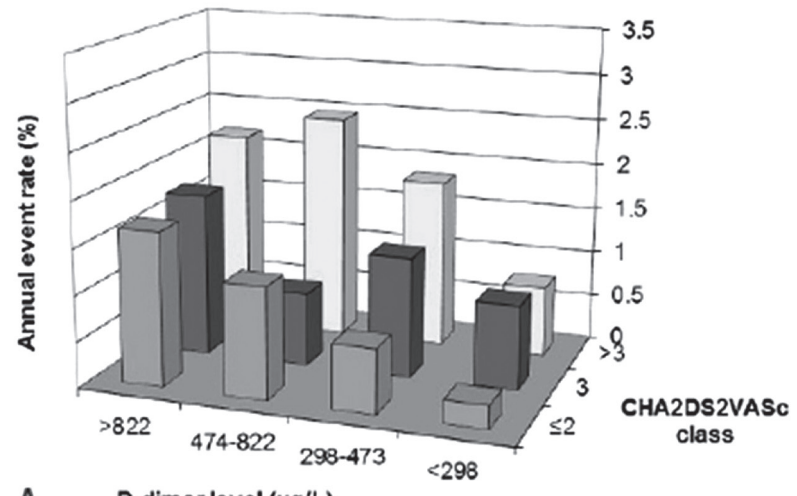

A D-dimer level $(\mu \mathrm{g} / \mathrm{L})$

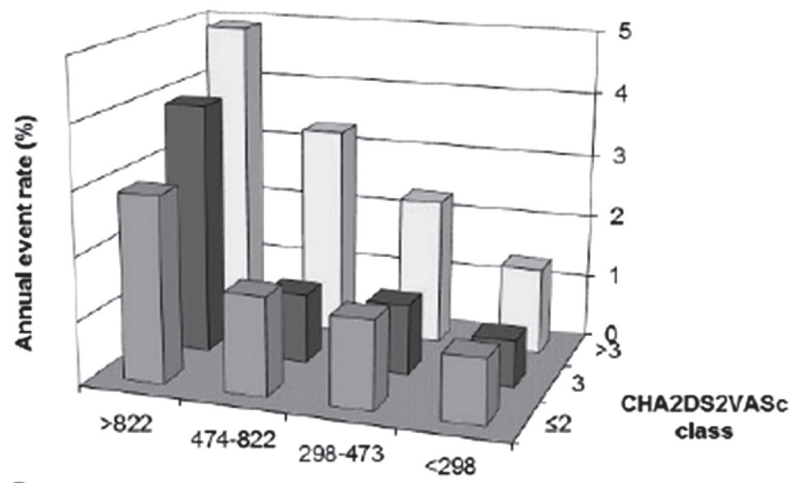

B D-dimer level ( $\mu \mathrm{g} / \mathrm{L})$

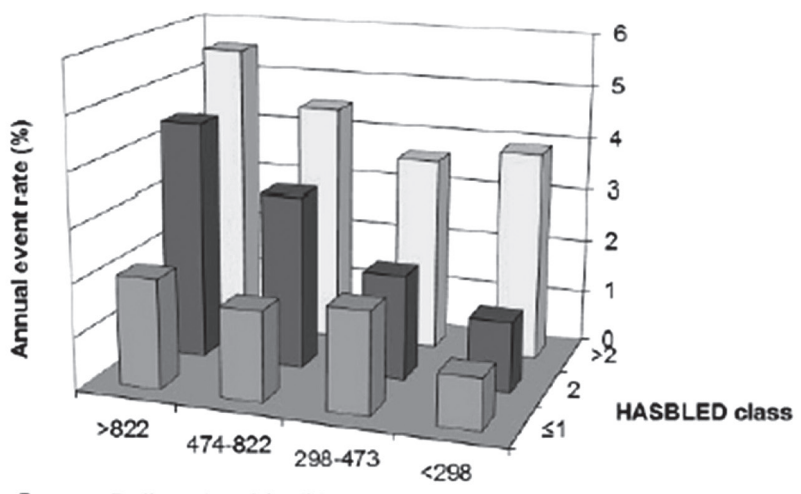

C

D-dimer level ( $\mu \mathrm{g} / \mathrm{L})$

図 1 D-ダイマーと $\mathrm{CHA}_{2} \mathrm{DS}_{2}$-VASc またはHAS-BLED ス コア別の年間イベント発症リスク（文献 30 より引用）

A: 脳卒中または全身性塞栓症

B: 心血管死

C: 大出血

療法による出血合併症を回避できる可能性もある.

\section{2）抗凝固療法の有効性・安全性との関連}

D-ダイマーは抗凝固療法により低下する ${ }^{24-26,30)}$ が, 心原性脳塞栓症の凝固立進状態には個人差が大 きく，ワルファリンが至適 PT-INR にコントロール されていても D-ダイマーが高值を示す症例があ $b^{24,25)}$. ワルファリン療法中の D-ダイマーが高い

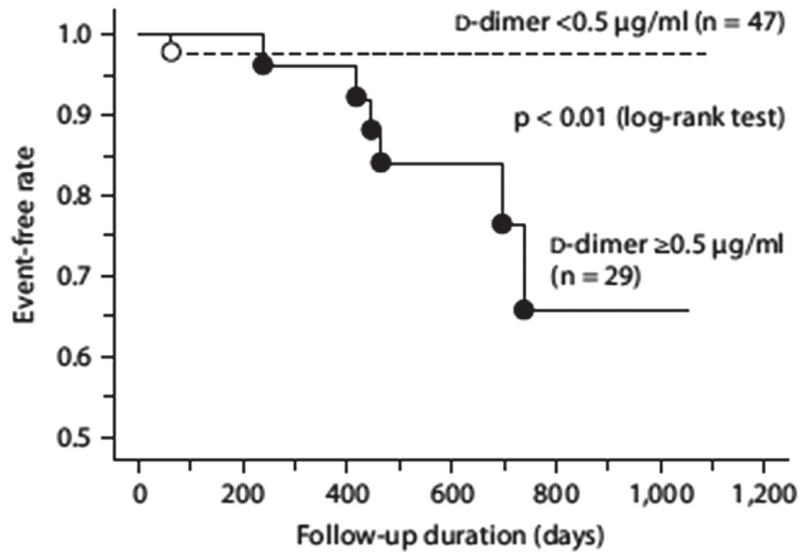

図 $2 \mathrm{CHADS}_{2}$ スコア 3 点以上でワルファリン療法中の非 弁膜症性心房細動患者における血栓塞栓性イベントの Kaplan-Meier 曲線 (文献 27 より用)

年間の血栓塞栓性イベント発症率は D-ダイマー高值

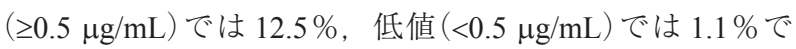
あった。

患者では脳梗塞発症リスクが高いことが示されてお り(図 2 $)^{24,25,27)}$ ，ワルファリンを調整してD-ダイマー を低下させれば，脳梗塞発症抑制効果が高くなる可 能性がある. DOACs は薬効を評価する適切な方法 がないので, APTTやPT と凝固線溶活性化マーカー を組み合わせた評価がワルファリンよりも有用な可 能性が考えられる。ただし，F1+2 以外の分子マー カーには「低下」という基準がなく，過剩な凝固抑制 は評価できない。

高度な内皮傷害を反映する vWF や D-ダイマーの 上昇は，抗凝固療法中の血栓塞栓症だけではなく， 出血とも関連することが報告されている ${ }^{28-30)}$ 。ワル ファリン療法下の出血リスクを予測する HAS-BLED スコア ${ }^{23)} に \mathrm{D}-$ ダイマーを組み合わせると，個別の 出血の予測精度が高くなることも示唆されている (図 1) ${ }^{28-30)}$.

\section{6. アテローム血栓性梗塞の病態評価}

高度なアテローム硬化やプラーク上での血栓形成 がみられる病態は，アテローム血栓性梗塞の発症リ スクが高い。これを鋭敏に反映するマーカーは，脳 梗塞発症・再発リスクの推定に有用と考えられるが, NVAF の D-ダイマーのように臨床的に測定可能で有 用性が示唆されるものは現時点ではない。研究的に 
は，脳梗塞発症のリスク因子である高度頸動脈狭窄 や抗血小板療法下の再発と PS や CD40L の関連が 報告されている。

\section{1）脳梗塞発症・再発リスクとの関連}

動脈硬化の程度の指標となる頸動脈の内膜中膜複 合体の厚さ (IMT) やプラークの性状は, 頸動脈超音 波検査を用いて簡単に評価することが可能である。 IMT と PS などの血小板活性化マーカーや炎症マー カーが相関することや，CD40L が不安定プラークの 破綻による脳梗塞の発症リスクと関連することが示 唆されている ${ }^{10,32-36)}$ 。 また, CD40L や血小板単球複 合体の高值例では再発が多く転帰が不良であること も報告されている37).

\section{2）抗血小板療法の評価}

PS は抗血小板療法により低下するが ${ }^{14-38)}$ ，抗血小 板療法の有無で比較するとオーバーラップの大きい 幅広い分布を示すため，薬効の指標に用いることは 困難である，抗血小板薬の効果をみる目的では，血 小板凝集能や VerifyNow ${ }^{\circledR}$ などによる血小板反応性 が評価されている ${ }^{3-5,38)}$ ，アスピリン療法下のアラキ ドン酸凝集やクロピドグレル療法下の ADP 凝集や PRU が高い患者群では心血管イベントが高率である ことが，冠動脈インターベンション患者などでは示 されている ${ }^{4,5)}$ 。しかし，脳梗塞を含む日本人の慢 性期アテローム血栓症患者では，アスピリン療法中 に残存しているシクロオキシゲナーゼ-1 活性や血 小板凝集能は再発と関連しないことが示された ${ }^{39)}$. 慢性期の安定した状態の脳梗塞患者では抗血小板薬 に対する反応性の個人差を評価する意義はそしく, 急性期や脳血管内治療など再発リスクの高い患者で 検討すれば有用性が示される可能性があると考えら れている。

\section{7. おわりに}

脳梗塞は複合的な要因で発症し，その病態は多様 で，同じ臨床病型でも再発リスクにはバラッキがあ る。脳梗塞は再発しやすい反面，再発予防を目的と した抗血栓療法中の頭蓋内出血のリスクも高い。抗 血栓薬の薬効には人種差や個人差があり，エビデン スの確立した抗血栓薬が個人に適当な抗血栓効果を 発揮しているかどうかはわからない。個人の脳梗塞
や頭蓋内出血のリスクを評価し，出血の危険性を最 小限に抑えながら脳梗塞発症を予防するためには, 個別の血栓止血学的評価は有用な情報になり得ると 考えられる，ただし，生体内で起こる包括的な止血 反応を in vitroの条件下で再現できる検査はないた め，それぞれの検査の特徵と限界を認識し，複数の 項目を組み合わせて総合的に評価することが重要と 考えられる。

著者の利益相反 $(\mathrm{COI})$ の開示 :

本論文発表内容に関連して開示すべき企業との利益 相反なし

\section{文献}

1）山崎昌子, 内山真一郎：脳血管障害の凝血学的検査 (特 集：脳血管障害 研究と診療の進歩)。東京女子医科大 学雑誌 77: 275-280, 2007.

2）北島勲：DOACs と凝固検查，一瀬白帝，丸山征郎，村 田満編著, 新 - 血栓止血血管学 検査と診療. 京都, 金芳堂，2015, 139-147.

3）山崎昌子, 内山真一郎：抗血小板薬の薬効評価. 東京 女子医科大学雑誌 84 (臨増): E49-56, 2014.

4) Aradi D, Kirtane A, Bonello L, Gurbel PA, Tantry US, Huber K, Freynhofer MK, ten Berg J, Janssen P, Angiolillo DJ, Siller-Matula JM, Marcucci R, Patti G, Mangiacapra F, Valgimigli M, Morel O, Palmerini T, Price MJ, Cuisset T, Kastrati A, Stone GW, Sibbing D: Bleeding and stent thrombosis on P2Y12-inhibitors: collaborative analysis on the role of platelet reactivity for risk stratification after percutaneous coronary intervention. Eur Heart J 36: 1762-1771, 2015.

5) Tantry US, Bonello L, Aradi D, Price MJ, Jeong YH, Angiolillo DJ, Stone GW, Curzen N, Geisler T, Ten Berg J, Kirtane A, Siller-Matula J, Mahla E, Becker RC, Bhatt DL, Waksman R, Rao SV, Alexopoulos D, Marcucci R, Reny JL, Trenk D, Sibbing D, Gurbel PA; Working Group on On-Treatment Platelet Reactivity: Consensus and update on the definition of on-treatment platelet reactivity to adenosine diphosphate associated with ischemia and bleeding. J Am Coll Cardiol 62: 2261-2273, 2013.

6) Price MJ, Berger PB, Teirstein PS, Tanguay JF, Angiolillo DJ, Spriggs D, Puri S, Robbins M, Garratt KN, Bertrand OF, Stillabower ME, Stillablower ME, Aragon JR, Kandzari DE, Stinis CT, Lee MS, Manoukian SV, Cannon CP, Schork NJ, Topol EJ; GRAVITAS Investigators: Standard- vs high-dose clopidogrel based on platelet function testing after percutaneous coronary intervention: the GRAVITAS randomized trial. JAMA 305: 1097-1105, 2011.

7) Collet JP, Cuisset T, Rangé G, Cayla G, Elhadad S, Pouillot C, Henry P, Motreff P, Carrié D, Boueri Z, Belle L, Van Belle E, Rousseau H, Aubry P, Monségu J, Sabouret P, O'Connor SA, Abtan J, Kerneis M, Saint-Etienne C, Barthélémy O, Beygui F, Silvain J, Vicaut E, Montalescot G; ARCTIC Investigators: 
Bedside monitoring to adjust antiplatelet therapy for coronary stenting. N Engl J Med 367: 2100-2109, 2012.

8) Hosokawa K, Ohnishi T, Fukasawa M, Kondo T, Sameshima H, Koide T, Tanaka KA, Maruyama I: A microchip flowchamber system for quantitative assessment of the platelet thrombus formation process. Microvasc Res 83: 154-161, 2012.

9) Hosokawa K, Ohnishi T, Sameshima H, Miura N, Ito T, Koide T, Maruyama I: Analysing responses to aspirin and clopidogrel by measuring platelet thrombus formation under arterial flow conditions. Thromb Haemost 109: 102-111, 2013.

10) Yamazaki M, Ohnishi T, Hosokawa K, Yamaguchi K, Yoneyama T, Kawashima A, Okada Y, Kitagawa K, Uchiyama $\mathrm{S}$ : Measurement of residual platelet thrombogenicity under arterial shear conditions in cerebrovascular disease patients receiving antiplatelet therapy. J Thromb Haemost 14: 17881797, 2016

11) Takano K, Yamaguchi T, Uchida K: Markers of a hypercoagulable state following acute ischemic stroke. Stroke 23: 194198, 1992.

12) Yamazaki M, Uchiyama S, Maruyama S: Alterations of haemostatic markers in various subtypes and phases of stroke. Blood Coagul Fibrinolysis 4: 707-712, 1993.

13) Uchiyama S, Yamazaki M, Maruyama S, Handa M, Ikeda Y, Fukuyama M, Itagaki I: Shear-induced platelet aggregation in cerebral ischemia. Stroke 25: 1547-1551, 1994.

14) Yamazaki M, Uchiyama S, Iwata M: Measurement of platelet fibrinogen binding and p-selectin expression by flow cytometry in patients with cerebral infarction. Thromb Res 104: 197-205, 2001.

15) Takano K, Yamaguchi T, Kato H, Omae T: Activation of coagulation in acute cardioembolic stroke. Stroke 22: 12-16, 1991.

16) Yasaka M, Yamaguchi T: Cardioembolic stroke revealed by increased hemostatic markers associated with intracardiac thrombus. Stroke 22: 1317-1319, 1991.

17) Sato M, Suzuki A, Nagata K, Uchiyama S: Increased von Willebrand factor in acute stroke patients with atrial fibrillation. J Stroke Cerebrovasc Dis 15: 1-7, 2006.

18) Wu N, Chen X, Cai T, Wu L, Xiang Y, Zhang M, Li Y, Song Z, Zhong L: Association of inflammatory and hemostatic markers with stroke and thromboembolic events in atrial fibrillation: a systematic review and meta-analysis. Can J Cardiol 31: 278-286, 2015.

19) O’Neal WT, Soliman EZ, Howard G, Howard VJ, Safford MM, Cushman M, Zakai NA: Inflammation and hemostasis in atrial fibrillation and coronary heart disease: The REasons for Geographic And Racial Differences in Stroke study. Atherosclerosis 243: 192-197, 2015.

20) Mahé I, Bergmann JF, Chassany O, dit-Sollier CB, Simoneau G, Drouet L; COAGFA Group: A multicentric prospective study in usual care: D-dimer and cardiovascular events in patients with atrial fibrillation. Thromb Res 129: 693-699, 2012.

21) Matsumoto M, Sakaguchi M, Okazaki S, Furukado S, Tagaya M, Etani H, Shimazu T, Yoshimine T, Mochizuki H, Kitagawa $\mathrm{K}$ : Relationship between plasma (D)-dimer level and cerebral infarction volume in patients with nonvalvular atrial fibrillation. Cerebrovasc Dis 35: 64-72, 2013.

22) Choudhury A, Chung I, Blann AD, Lip GY: Platelet surface CD62P and CD63, mean platelet volume, and soluble/platelet $\mathrm{P}$-selectin as indexes of platelet function in atrial fibrillation: a comparison of "healthy control subjects" and "disease control subjects" in sinus rhythm. J Am Coll Cardiol 49: 19571964, 2007.

23）日本循環器学会：循環器病の診断と治療に関するガイ ドライン (2012 年度合同研究班報告) 心房細動治療(薬 物) ガイドライン (2013 年改訂版). http://www.j-circ.or.jp/ guideline/pdf/JCS2013_inoue_h.pdf (2017.4.4).

24) Vene N, Mavri A, Kosmelj K, Stegnar M: High D-dimer levels predict cardiovascular events in patients with chronic atrial fibrillation during oral anticoagulant therapy. Thromb Haemost 90: 1163-1172, 2003.

25) Nozawa $T$, Inoue $H$, Hirai $T$, Iwasa A, Okumura $K$, Lee JD, Shimizu A, Hayano M, Yano K: D-dimer level influences thromboembolic events in patients with atrial fibrillation. Int J Cardiol 109: 59-65, 2006.

26) Weitz JI, Connolly SJ, Patel I, Salazar D, Rohatagi S, Mendell J, Kastrissios H, Jin J, Kunitada S: Randomised, parallelgroup, multicentre, multinational phase 2 study comparing edoxaban, an oral factor Xa inhibitor, with warfarin for stroke prevention in patients with atrial fibrillation. Thromb Haemost 104: 633-641, 2010.

27) Sadanaga T, Kohsaka S, Ogawa S: D-dimer levels in combination with clinical risk factors can effectively predict subsequent thromboembolic events in patients with atrial fibrillation during oral anticoagulant therapy. Cardiology 117: 31-36, 2010.

28) Roldán V, Marín F, Muiña B, Torregrosa JM, HernándezRomero D, Valdés M, Vicente V, Lip GY: Plasma von Willebrand factor levels are an independent risk factor for adverse events including mortality and major bleeding in anticoagulated atrial fibrillation patients. J Am Coll Cardiol 57: 2496-2504, 2011.

29) Christersson $\mathrm{C}$, Wallentin L, Andersson U, Alexander JH, Ansell J, De Caterina R, Gersh BJ, Granger CB, Hanna M, Horowitz JD, Huber K, Husted S, Hylek EM, Lopes RD, Siegbahn A: D-dimer and risk of thromboembolic and bleeding events in patients with atrial fibrillation-observations from the ARISTOTLE trial. J Thromb Haemost 12: 14011412,2014

30) Siegbahn A, Oldgren J, Andersson U, Ezekowitz MD, Reilly PA, Connolly SJ, Yusuf S, Wallentin L, Eikelboom JW: Ddimer and factor VIIa in atrial fibrillation - prognostic values for cardiovascular events and effects of anticoagulation therapy. A RE-LY substudy. Thromb Haemost 115: 921-930, 2016.

31) Choudhury A, Chung I, Panja N, Patel J, Lip GY: Soluble CD40 ligand, platelet surface CD40 ligand, and total platelet CD40 ligand in atrial fibrillation: relationship to soluble Pselectin, stroke risk factors, and risk factor intervention. Chest 134: 574-581, 2008.

32) Koyama H, Maeno T, Fukumoto $S$, Shoji T, Yamane $T$, Yokoyama H, Emoto M, Shoji T, Tahara H, Inaba M, Hino M, Shioi A, Miki T, Nishizawa Y: Platelet P-selectin expression is associated with atherosclerotic wall thickness in carotid ar- 
tery in humans. Circulation 108: 524-529, 2003.

33) Ramsis N, El-Hawary AA, Ismail E: Relation between carotid intima-media thickness, platelet surface activation and endothelial cell markers. Haemostasis 28: 268-275, 1998.

34) Shimizu M, Kohara S, Yamamoto M, Ando Y, Haida M, Shinohara Y: Significant relationship between platelet activation and intra-media thickness of the carotid artery in patients with ischemic cerebrovascular disease. Thromb Res 117: 647-652, 2006.

35) Kinsella JA, Tobin WO, Tierney S, Feeley TM, Egan B, Collins DR, Coughlan T, O’Neill D, Harbison J, Madhavan P, Moore DJ, O'Neill SM, Colgan MP, Doherty CP, Murphy RP, Saqqur M, Moran N, Hamilton G, McCabe DJ: Increased platelet activation in early symptomatic vs. asymptomatic carotid stenosis and relationship with microembolic status: results from the Platelets and Carotid Stenosis Study. J Thromb Haemost 11: 1407-1416, 2013.

36) Novo $\mathrm{S}$, Basili S, Tantillo R, Falco A, Davì V, Novo G, Corrado E, Davì G: Soluble CD40L and cardiovascular risk in asymp- tomatic low-grade carotid stenosis. Stroke 36: 673-675, 2005.

37) Lukasik M, Dworacki G, Kufel-Grabowska J, Watala C, Kozubski W: Upregulation of CD40 ligand and enhanced monocyte-platelet aggregate formation are associated with worse clinical outcome after ischaemic stroke. Thromb Haemost 107: 346-355, 2012.

38) Grau AJ, Reiners S, Lichy C, Buggle F, Ruf A: Platelet function under aspirin, clopidogrel, and both after ischemic stroke: a case-crossover study. Stroke 34: 849-854, 2003.

39) Nagatsuka K, Miyata S, Kada A, Kawamura A, Nakagawara J, Furui E, Takiuchi S, Taomoto K, Kario K, Uchiyama S, Saito K, Nagao T, Kitagawa K, Hosomi N, Tanaka K, Kaikita K, Katayama Y, Abumiya T, Nakane H, Wada H, Hattori A, Kimura K, Isshiki T, Nishikawa M, Yamawaki T, Yonemoto N, Okada H, Ogawa H, Minematsu K, Miyata T: Cardiovascular events occur independently of high on-aspirin platelet reactivity and residual COX-1 activity in stable cardiovascular patients. Thromb Haemost 116: 356-368, 2016. 